\title{
Rising of Regional Development Proposed by Complementary Law 123/2006 in Bidding: Comparing Bidding From Two Towns in the Southern Cone of the State of Rondônia - Brazil
}

\author{
Aline Cristina Helfenstein ${ }^{1}$, Douglas Fernando Batista Neis ${ }^{1}$, Elielza Camargo Souza ${ }^{1}$, Flávia Regina Alves de Hungria \\ Folador $^{1}$, Marlene Valério dos Santos Arenas ${ }^{1} \&$ Valmir Batista Prestes de Souza ${ }^{1}$ \\ ${ }^{1}$ Public Administration (PROFIAP), Rondônia Federal University, Rondônia, Brazil \\ Correspondence: Douglas Fernando Batista Neis, Professional Master's Program in Public Administration (PROFIAP), \\ Rondônia Federal University, Rondônia, Brazil.
}

Received: June 7, 2020

doi:10.5430/ijba.v11n5p10
Accepted: August 3, 2020

Online Published: August 14, 2020

URL: https://doi.org/10.5430/ijba.v11n5p10

\begin{abstract}
This study was intended to assess whether the bidding notices of Cerejeiras and Cabixi had put regional development foward, under the terms of Complementary Law 123/2006. The research is exploratory, quantitative, with a longitudinal cut, based on the bidding notices from the health and education departments, which were carried out in 2017 and 2018, extracted from transparency portals of the studied towns. The notices were organized and classified in a table, identifying each one of the items covered by the Complementary Law, comparing them with the law and what is contained in the notices. It was checked that the city halls apparently have little knowledge or clarification about the application of the law, since its public notices establish more tiebreakers criteria for Micro and Small Enterprises (MSEs) than other benefits allowed by law. It was also observed that the provided parts by law are not used. The construction contract notices did not provide for the subcontracting of MSEs. Most notices presented the preference for hiring local and regional companies incorrectly. There were no notices with quotas for the exclusive supply of MSEs in bids for goods of a divisible nature. In addition, it was noted that public agents from these towns need training related to the topic to apply the law and thus foster regional development correctly. Most notices presented the preference for hiring local and regional companies incorrectly. There were no notices with quotas for the exclusive supply of MSEs in bidding for goods of a divisible nature. In addition, it was noted that the towns need training related to the topic to apply the law and thus foster regional development correctly.
\end{abstract}

Keywords: regional development, micro and small enterprises, bidding

\section{Introduction}

Complementary Law no. 123, of December 14, 2006, had instituted in Brazil the new National Statute for Micro and Small Enterprises. Among the innovations of the new statute, the redefinition of the rules applicable to Micro and Small Enterprises stands out, establishing as the main criterion for framing the annual revenue of enterprises. Thus, for the due tax and legal effects, with the most recent changes promoted by Complementary Law no. 155, of October 27, 2016, it is considered as a micro enterprise the simple company and the entrepreneur referred to in art. 966 of the Civil Code, duly registered, which generated maximum annual revenue of up to $R \$ 360.000,00$ (three hundred and sixty thousand reais); the small business is the one that, under the same conditions above, generates annual revenue between $\mathrm{R} \$ 360.000,00$ (three hundred and sixty thousand reais) and $\mathrm{R} \$ 4.800 .000,00$ (four millions and eight hundred thousand reais) (BRASIL 2016).

The creation of Complementary Law 123/2006 came about with the objective of expanding the market, economic and tax conditions of small businesses. In this regard, it defines specific criteria for taxation, access to loans and differentiated treatment in public bids. To find out how this law has changed the structure of public procurement and also the development of micro and small businesses, several studies have been developed in recent years.

Freitas (2012) studied the impact of differentiated treatment given to enterprises on sustainability and the economy; Masera (2008) sought to understand whether the public administration can stimulate the development of enterprises; Chapuis (2019) studied the purchasing processes of a public educational institution, delimiting the initiatives proposed by the institution so that small local suppliers had access to public purchases as well as the factors that influence the 
participation of this type of company in bidding; Baradel (2011) analyzed bidding as a public policy instrument for development and Cabral, Reis and Sampaio (2015) analyzed the participation of micro and small enterprises in public bidding.

In this sense, the importance of studying this research problem is verified, to verify if the public agencies of the State of Rondônia are managing to apply the legal mandates in their bidding and thus promote the development of micro and small enterprises, which in this work we will call MSEs. Thus, the central problem of this research is: did Cerejeiras and Cabixi in Rondônia promote the sustainable development of MSEs through their bidding notices, in the years 2017 and 2018 ?

As a general objective of this work, it is intended to verify whether the bidding notices which were carried out in the years 2017 and 2018 of the Health and Education Departments of the towns of Cerejeiras and Cabixi had put regional development foward, as recommended by Complementary Law 123/2006.

The specific objectives are: (1) Mapping the criteria established by CL 123/2006 in the bidding notices carried out by the Health and Education Departments of Cabixi and Cerejeiras, in the years 2017 to 2018; (2) Checking if items I, II, III and paragraph 3 of art. 48 of Complementary Law 123/2006, art. 3 of Law 8.666 / 93 and its amendments were observed; (3) Analyzing through the collected data, how much the Complementary Law is used to promote the regional development of these towns and the region where they are installed.

The delimitation of the health and education departments was due to the fact that these departments are responsible for the largest volume of purchases by the towns and, in this scope, the choice of Cerejeiras and Cabixi was due to the convenience that the transparency portal of these towns contains the data needed for this research in an orderly manner and belong to the same micro-region in the state, the southern cone.

To answer the question, this work is divided into four chapters, starting with the present, introductory, followed by the theoretical reference, which will support the empirical research and the methodology, where the tools and methods used are. Afterwards, the analysis and discussion of the data is carried out, where the results found are presented, the final considerations about the work and, finally, it was related the references which were used.

\section{Theoretical Reference}

The conceptual framework that guides this research is the theory of endogenous development. This theory is based on the concept that purchases made by small enterprises and regional enterprises favor local development (CHAPUIS, 2019).

Along the same line, Amaral Filho (1996) states that endogenous development is a process in which the values of local production are reinforced, which results in the generation of jobs, products and income for the place or region where it is applied.

According to Braga (2002), endogenous local development occurs through economic insertion and the consequent replacement of competition among large geographic spaces, by competition among locations such as cities and micro-regions.

Chapuis (2019) adds that the main cause of the discrepancy in income distribution and the consequent deficit economic development is due to inequalities in the market.

The changes proposed by the creation of Complementary Law 123/2006, have originated from changes that have been occurring in the country and worldwide for some time, and with these changes the consequent need for the State to intervene in economic development. Amaral Filho (1996) shows that because of globalization, decentralization, financial crises and changes in productive and institutional scenarios, the State is under pressure to develop instruments and strategies for regional development, generating changes in terms of regulation.

In order to meet the need for State intervention in public development policies, Brazil, in its bidding law, Law 8.666 / 1993, art. 3 establish that bidding must promote sustainable development. What Freitas (2012) complements when he defines that sustainability is made up of broader issues than environmental ones, such as economic, political and social.

To reinforce what was proposed in the amendment of art. 3 of the Bidding Law, in 2006 the Statute of Micro and Small Enterprises was enacted (Complementary Law 123/2006), with the objective of defining criteria for expanding competitive conditions for SMEs and thus facilitating the permanence of this segment in the market, providing for differentiated treatment in the payment of taxes, access to credit and differentiated treatment in government bidding of all spheres, thus promoting local endogenous development (BRASIL, 2006).

The differentiated treatment provided for in Brazilian legislation is intended to effect regional development, of micro 
and small enterprises by public agencies through public bidding, as established by Amaral Filho (1996) as the responsibility of the State. In this sense, the law foresees some aspects that will be verified in the present work: a) Bidding with a value up to $\mathrm{R} \$ 80.000,00$ will be destined exclusively to MEs and SEs, and may be opened to other enterprises when there are not at least three competitive suppliers; b) Subcontracting MEs and SEs in services and construction contracts; c) Bidding for the acquisition of goods, whose nature is divisible, establishing a $25 \%$ quota for MEs and SEs; d) Preference in hiring regionally based enterprises; e) Rising of sustainable national development (BRASIL, 2006).

The creation of the Microenterprise Statute took place as a form of effective public policy inclusion and better competition conditions for small enterprises that do not have as many competition mechanisms to the detriment of large enterprises. According to Nascimento (2015), public policies occur through legal acts that guide and determine their applications, that is, laws, decrees, resolutions, consortia and other rules. In this sense, the creation of the law which is analyzed in this work.

The mere creation of a law does not guarantee the effectiveness of the proposed public policy development. It is necessary that the regulated entities by law to commit themselves to applying these laws. This is because sometimes the laws establish optional criteria, or still, loopholes in other laws are sought in order not to enforce them.

Freitas (2012) investigated whether the differentiated treatment given to micro and small enterprises is a skillful way to guarantee the social and economic sustainability of these enterprises. To this end, it carried out a bibliographic analysis in which it found that sustainability in public purchases goes beyond environmental issues, as it reaches social, ethical, legal, political and economic dimensions. A limitation that Freitas (2012) found is that the legislation on the subject is recent, and therefore it not very widespread, when compared to the USA, and that there are few scientific works in this area.

Masera (2008) researched how public administration stimulated the development of Micro and Small Enterprises and analyzed whether these stimuli are according to Complementary Law 123/2006 and Federal Decree $n^{\circ}$ 6.204/07. In his study, he used Peter Evans' approach, to study the placement of legislation in the economic bias of the country, verifying that both public agents and businessmen need more knowledge and preparation for the status of MSEs to be better applied.

Baradel (2011) analyzed how bidding can serve as a public policy instrument for regional development. In his study he found that bidding from the State of São Paulo take into account territorial decentralization, thus contributing to regional economic development. In order to verify whether this characteristic would produce the expected results, he analyzed the face-to-face and electronic auctions of two units of the University of São Paulo located in the state's countryside. He found that regional development did not occur in the two units, concluding that advances and other public policies are needed to raise regional development.

Cabral, Reis and Sampaio (2015) analyzed the participation and success of MSEs in public bids based on legislation aimed at differentiated treatment of this business segment. To this end, they analyzed data from 542 bids from a given federal agency, from 2005 to 2011. These authors concluded that through the change in legislation, there was a significant increase in the participation of MSEs in the bids of the studied agency, but this fact did not guarantee success to the segment. Through the results of the research, they also observed that strategic factors related to competitiveness intervene in the success of MSEs in public purchases.

MEs and SEs are recognized for their importance in the national economy, for both the generation of jobs and their geographic distribution, however they face difficulties in the competitive market (MASERA, 2008). Collaborating with the economic importance of MSEs, are Barreto et al. (2014) who state that MSEs are responsible for most of the labor employed in Brazil and Rocha et al. (2013) who present data from IBGE, where they find that $60 \%$ of the jobs generated in Brazil come from MEs and SEs, with the main sectors they cover are commerce, services, industry and civil construction, in that order.

Despite the economic importance that MSEs represent, they face several challenges for their maintenance and permanence in the market. For Masera (2008), the main difficulties faced by MSEs are linked to fundraising to build the necessary infrastructure and pay taxes. Confirming this, Barreto et al. (2014) say that the main difficulties of MSEs, among others, are the lack of capital, planning and public policies. These difficulties were also evidenced by Cabral, Reis and Sampaio (2015) and by Baradel (2011).

The importance of the participation of MEs and SEs in bids is due to the fact that, according to Freitas (2012), public contracts are one of the ways that the government has to intervene in the economy, as they represent the largest buyer in Brazil. Cunha and Bourlegat (2016) state that public purchases can also be useful to boost the economy, generate jobs, 
protect small businesses and reduce regional disparities. Such statements demonstrate the importance of using the Complementary Law 123/2006 in public bidding notices.

For Ferreira and Giusti (2012) the creation of the Complementary Law represents that public bids have a social function, that is, they are also aimed at promoting economic development, which corroborates the idea of the State's responsibility in promoting local endogenous development. Barreto et al. (2014), interviewed those who were responsible for MSE bids, where they found that these enterprises find in bids an opportunity for growth, corroborating with Ferreira and Giusti (2012). Nascimento (2015) states that the government benefits itself from contracting and also promotes the development of MEs (Micro Enterprises) and SEs (Small Enterprises) through preferential bids.

Braga and Xavier (2011), in a study, carried out on the impact of the Statute of MEs and SEs on the development of public purchases in the State of Ceará, comparing the financial years 2006 to 2008, concluded that in terms of values, an increase of $164.87 \%$ was obtained, thus demonstrating that the evolution of the participation of MSEs was effective in public purchases.

Corroborating with the results obtained by the authors, Nascimento (2015) highlights the success of the use of bidding as a stimulus to public policies for MSEs, highlighting the reduction of disparities between MSEs and large enterprises in the bidding processes, in other words, it verifies the effective application of that proposed by Complementary Law $123 / 2006$ for the object of analysis by the author.

Following the same line of study, Cunha and Bourlegat (2016), point out that Complementary Law 123/2006 together with Law 8.666 / 1993, provided greater transparency to spending on public money with lower cost in acquisitions, in addition to greater participation of MSEs in bids, thus promoting greater equality among enterprises, whether large or small, or still operating for more or less time in the market.

In terms of law enforcement, Nascimento (2015) found that the Federal Institute of Science and Technology Education of Pernambuco (IFPE) - Campus Recife, in the period from 2009 to 2013, was effective in using the Statute of MEs and SEs and consequently promoted the development of MSEs in their bids.

Also according to Nascimento (2015), the social governmental function is effective when the bids promote participation and differentiated treatment to MSEs, confirming this with his research, which found that $91.83 \%$ of the purchases made through the electronic auction of the IFPE-Campus Recife were made through hiring MSEs.

Cabral, Reis and Sampaio (2015) found that the public policy proposed by the differentiated treatment of MSEs in public bids contributes to increase the participation of this segment of enterprises in the competitions, however they observed that in the higher value bids, their participation is lower. Through the research of these authors, it can be concluded that the difficulties of MSEs are real, since in the higher value bids, the investment and necessary expenses are greater, which perhaps reflects the lower participation of these enterprises.

The next chapter deals with the methodological procedures used for the development of this research.

\section{Methodology}

This research is exploratory, as it seeks to address the issue of promoting endogenous development under a new reality, in the State of Rondônia, in relation to the promotion of micro and small enterprises (SAUNDERS, LEWIS and THORNHILL, 2016). The quantitative approach was used, with a longitudinal cut and, as a strategy for data collection, document analysis was adopted (CRESWELL, 2010).

For the development of this research, bibliographic surveys were initially carried out on published articles, in Law 8.666/1993 and Complementary Law 123/2006, in order to delimit important aspects related to the theme, definitions, criteria, as well as the theory that involves the subject.

The hypothesis that will be tested is that Cerejeiras and Cabixi have not promoted endogenous regional development through their instruments for selecting suppliers of materials, services and works.

For the collection of data, it was used bidding notices which were performed in 2017 and 2018, aimed at serving the health and education departments of Cerejeiras and Cabixi, in the State of Rondônia. According to Saunders, Lewis and Thornhill (2016) the data used are of the secondary type and are available for popular consultation, through the transparency portal. The information obtained was organized in a table, using Microsoft Excel version 2013, and the variables analyzed were items I, II and III and paragraph 3 of art. 48 of Complementary Law 123/2006 and art. 3 of Law 8.666/93. The notices were separated by municipality, followed by type of supply, in other words, services, works and purchase of goods and/or materials, and thus quantified the aspects of the legislation in each notice. 
The table below represents the number of notices analyzed in this research, distributed by city, year and type of contract.

Table 1. Elaborated by the authors

\begin{tabular}{lllll}
\hline Type of Contract & Cerejeiras & \multicolumn{2}{l}{ Cabixi } \\
\cline { 2 - 5 } & 2017 & 2018 & 2017 & 2018 \\
\hline Construction & 1 & 8 & 1 & 3 \\
\hline Goods and Materials & 34 & 50 & 31 & 28 \\
\hline Services & 8 & 9 & 14 & 05 \\
\hline Total & 43 & 67 & 46 & 36 \\
\hline
\end{tabular}

The sample was chosen for convenience since they are towns belonging to the same micro region, Southern Cone of the State, and they are out of the axis of federal highway BR 364 (where are the main towns of the State). The two towns are practically the same distance from Vilhena, which is the region's pole town, with Cerejeiras is 125 kilometers away and Cabixi is 128 kilometers away. It is observed that the two towns are neighbors, in order to reach either one, you must leave federal highway BR 364, passing through Colorado do Oeste town, you must choose a roundabout to go to Cerejeiras or Cabixi. Thus, it is understood that the two towns have equal conditions of isolation and access to suppliers. In addition, these towns present complete data on their bids on their respective transparency portals.

The next chapter will present the analysis and discussion of the researched data.

\section{Data Analysis and Discussion}

The analysis of the data and discussion of the results was carried out separating the nature of the contract, so that it was possible to better analyze the criteria of the Law that could be applied in each type of contract. To this end, this chapter is divided into three sub-chapters: contracting public constructions; contracting services; and acquisition of goods or materials.

\subsection{Contracting Public Constructions}

Regarding to public bids for contracting public constructions, it was observed that the City Hall of Cerejeiras considered only the tiebreaker criteria for micro and small enterprises.

Of the nine notices which were analyzed, six could have been used to hire MSEs, since the amounts were below $\mathrm{R} \$ 80.000,00$. The nine ones could have provided for the subcontracting of MSEs, but there was not such provision in the notice as provided by Complementary Law 123/2006. Nor did any type of preference has been foreseen in the public notices for regionally based enterprises, such as a tiebreaker preference.

In this sense, the only criterion that was used in any way to promote sustainable development was the establishment of rules for a tiebreaker in case it occurs with MSE, concluding that in public bids for contracting public constructions, the City Hall of Cerejeiras does not have promoting endogenous regional development.

Cabixi carried out four bids for contracting public constructions in the period which was studied, and for one of them it was not available to access the notice. The values of the constructions vary between $R \$ 476.534,55$ and $R \$ 741.913,73$. It was observed that all of the three analyzed bids for contracting public constructions of that town, none of them could be destined to the exclusive contracting of MSEs because they were constructions estimated above $\mathrm{R} \$ 80.000,00$ and, consequently, they are not considered as common services.

Regarding the other promotion criteria to MSEs, the town of Cabixi could foresee in its public notices the subcontracting of MSEs within the limit of 25\%, which made it unfeasible with item 28.10, in the contractor's obligations section:

"28.10 - Perform all contracted services directly; except for the hypothesis of partial subcontracting, duly authorized by the contractor, which can only be concluded with accepted enterprises, after determining their Legal Capacity, Technical Capacity, Financial Suitability and Tax Regularity "(CABIXI, 2018).

The clause in question could mention MSEs and present a text that could be more suggestive for hiring than restrictive. This fact would make large contracted enterprises more sensitive to subcontracting MSEs. 
It was not estimated, in the construction notices of the town of Cabixi in the years of 2017 and 2018, the benefits for enterprises headquartered locally or regionally. In all analyzed notices, it was possible to verify only the tiebreaker criterion with MSEs and the possibility of an additional deadline for delivering the documents with some restriction.

It is observed that the bids for the contracting public constructions in Cabixi, as well as in Cerejeiras, did not promote regional development in an ideal way during the period it was studied. Where they strictly keep the law in the required precepts, leaving the optional ones aside.

\subsection{Contracting Services}

In bids concerned to contracting services, it was found that the town of Cerejeiras is moving towards a more effective promotion of hiring MSEs, but it is not yet in a very significant way. Several notices did not mention an estimated cost for contracting, however, by analyzing the specifications of the object, it can be inferred that among the seventeen bids that were carried out, fourteen could have been destined exclusively for MSEs, but only half of them was.

Regarding to services of a divisible nature, there was only one bidding process that could have the services divided into batches and, thus, establish a quota for MSEs, as they are decoration services, buffet and rental of sound equipment to attend a single specific event. In this sense, it is understood that the services could have been divided into batches and allocate a certain quota for hiring MSEs.

It was foreseen, in the notices of Cerejeiras, the establishment of an advantage for enterprises headquartered locally or regionally, but it was not carried out in the right way. It was written in six of the analyzed notices expression similar to the one below, varying only the type of service:

"Furthermore, I inform you that, as it is a Contracting of a specialized company for the provision of preventive and corrective maintenance services, in the Air Conditioning and Air Curtains, there is a need for all possible interested parties to have their headquarters in the town of Cerejeiras, or in any city in the Conesul State of Rondônia, as they are the only ones that are able to perform the services, [...] "(CEREJEIRAS, 2017).

It is observed that such placement is a condition, which restricts the participation of other enterprises. In contrast to the text above, other notices provide:

"3.2 Priority will be given to hiring micro-enterprises or small businesses headquartered locally up to the limit of ten percent of the best valid price presented by non-local businesses, in situations where the offers presented by micro businesses or small businesses headquartered locally are higher than the lowest price;

3.3. In the event of non-contracting of micro-enterprises or small businesses based in the locality, the priority passes to the MICROREGION enterprises of Colorado do Oeste up to the limit of ten percent of the best valid price in situations where the offers presented by the micro-enterprises or small enterprises headquartered in the MICRO-REGION of Colorado do Oeste, are higher than the lowest price of the remaining enterprises that may qualify as ME or SE outside the Micro Region of Colorado do Oeste in classificatory order; (CEREJEIRAS, 2018) ".

Comparing the two sections of two different notices (which are the standard model in the other ones), there is a conflict of information in their preparation. In one moment, the bidding is restricted in the "justification for hiring" saying that enterprises need to be headquartered locally, while in other notices, after April 2018, the hiring preference for local enterprises is established under "conditions of participation".

The interest of Cerejeiras City Hall in promoting the endogenous regional development in service bidding is perceived, since in all public bidding some benefit criteria were foreseen for MSEs and exclusive bidding for regional enterprises form a significant number. However, notices need to be adapted to properly comply with legislation and promote such development without restricting competition.

Similarly, Cabixi has sought to promote the participation of MSEs in its bidding for contracting services, since all bidding promoted for this type of contract provided for some benefit or differentiated treatment for MSEs, even if they are the minimum tiebreaker criteria and deadline for delivering outstanding documents.

In spite of this, it was observed that among nineteen bids analyzed, seventeen had conditions to be destined to exclusive ME / SE contracting, however, only eleven established such criteria. The reasons for non-exclusivity were not identified in the present research, due to the limited time and method. As it was the minority of the bids that were not destined exclusively to MSEs, it can be inferred that it is because they do not have MSEs with adequate technical capacity regionally for such providing service.

Regarding judgment criteria with preference for regionally based enterprises, the City Hall of Cabixi seems to make a mistake, in which it restricted the participation of enterprises that were not based in the towns of Cabixi, Cerejeiras and 
Colorado do Oeste (micro region) in nine bids, whose services were related to executions more focused on the locality, such as tire repair services, air conditioning maintenance, etc.

In this regard, the two towns are concerned with hiring regional enterprises for services to be performed on the premises of the City Hall and its sectors. This is a valid concern, since enterprises based far from the town will have greater difficulty in executing the contract and the risk of subcontracting is greater. However, to prohibit the participation of other enterprises is to restrict competition, which goes against the General Bidding Law 8.666/93, and in the case of Cabixi the situation is aggravated, as it does not establish the preference for regional enterprises as in Cerejeiras elsewhere, it only restricts the participation of other enterprises.

Finally, it is concluded that the towns do not have sufficient knowledge about the Complementary Law 123/2006 to prepare a bidding notice with competition from several enterprises but adding advantages for regionally based enterprises.

\subsection{Acquisition of Goods and/or Materials}

When the notices for the purchase of goods or materials from Cerejeiras were analized, it was observed that among the 85 notices analyzed, several of them did not have a reference value to ascertain whether they could be destined exclusively to MSEs. In order to analyze in the best possible way, the detailed objects in the term of reference were checked, in order to have an idea of the estimated cost. After this analysis, there were 24 notices for proposals that cannot be predicted without more detailed research on how much the contract would be estimated.

The notices that were possible to delimit the reference value below $\mathrm{R} \$ 80.000,00$, either because it appears in the document, or because these are known to be low-cost products, forty-nine notices were considered able to exclusive bidding, but the City Hall of Cerejeiras has delimited such exclusivity in thirty-two notices.

Regarding the definition of advantages in the judgment of proposals for local enterprises in the bidding notices, until April 2018, Cerejeiras justified the use of face-to-face trading as the chosen modality, in bidding aimed at the purchase of products with fractional or perishable delivery, claiming that such supply should be made by local or regional enterprises, better serving the town because of the object. A milestone should be noted from April 2018 onwards, where the public notices started to include preference criteria in up to $10 \%$ of the contract value, in the following order: 1st MSEs based in Cerejeiras; 2nd MSEs based in the region (delimiting this region); 3rd MSEs from other locations. This change solved a problem that existed in the public notices and started to promote local and regional development more effectively. Of the total bids analyzed, eight were carried out along these lines.

As for the allocation of quotas for the exclusive supply of MSEs in the acquisition of goods of divisible nature, it was found that Cerejeiras carried out 35 bids where the goods were of a divisible nature, however, it did not present the delimitation that a certain amount of the supply was destined to the MSEs.

It is noticed that in Cabixi there is some confusion with the interpretation of Complementary Law 123/2006. Just like the other types of contracting, bidding for supplying goods and materials are marked by errors and successes. Among the fifty-five analyzed notices, forty-three should be destined exclusively to MSEs, due to the amount to be auctioned, however twenty-two bids had exclusive treatment. It was also observed that, in several notices, the header is shown as exclusive bidding for MSEs and in the conditions of participation criteria are defined only in the event of a tie, or even locally, followed by regionally, within the limit of $10 \%$ of the total bid amount.

Other failed notices, in the definition of who can participate in the bidding, include the following wording:

"9.1. Only enterprises that are regularly established in the Regional Scope (Cabixi-RO, Colorado do Oeste-RO, Cerejeiras-RO and Vilhena-RO) may participate in this Bidding whose purpose and line of activity is compatible with the object of this Bidding;" (CABIXI, 2017).

This item in the notice is observed not as a preference for regional enterprises, but as a restriction on competition. In view of the alarming data, Municipal Decree 050/2017 was mentioned, which is mentioned in the text, while it was found that it is based on the Micro and Small Company Statute, not adding new rules in the sense of restricting bids. In some of these bids the restriction could be understandable due to the nature of the product or the form of supply. However, there were bids of this type for the acquisition of graphic materials, expedient material and supply of fabrics.

More assertively, some notices established the following:

"Based on $\S 3$ of art. 48 of Complementary Law 147/2014, combined with the provisions of Municipal Decree $\mathrm{N}^{\circ} 050$ of February 1, 2017, It is established the preference for hiring micro and small businesses based in Cabixi or regionally, up to a limit of $10 \%$ ( ten percent) above the best valid price. 
I - The priority will be for ME / SE based in the town of CABIXI - RO;

II - In the absence of ME and SE headquartered in the town of Cabixi, priority may be given to enterprises located at the regional level, covering the towns of Colorado do Oeste, Cerejeiras, Pimenteiras, and Vilhena-RO "(CABIXI, 2018)

As can be seen, criteria for preference rather than restriction of competitiveness are already defined here.

In general, rightly or wrongly, Cabixi added preference or advantages to local or regional enterprises in twenty-nine of analyzed public notices. This value, combined with the information mentioned above, corroborates the idea that there are doubts about the correct application of CL 123/2006. This can also be seen through the allocation of quotas for MSEs in bids whose supply of goods is divisible. In a single bidding, a hybrid nature of participation was established, restricting some batches to MSEs and opening two other batches in the bidding to wide access. In other words, among the 16 bids that the nature of the supply allowed for the establishment of quotas, none were carried out, only this specific hybrid bidding case.

Comparing the two towns in this type of purchase, it appears that the two City Halls need training and information regarding the legal precepts on the promotion of MSEs and regional development. However, Cerejeiras seems to be a little more organized, mainly due to the change in its public notices, which started to be elaborated more correctly after a certain date.

\subsection{Empirical Results Compared to Other Realities}

The results found in the present empirical study demonstrate the lack of promotion of regional development in its bids by the towns which were studied here. This fact is verified through the absence of clear rules (and according to the law) in the notices, of preference criteria for MSEs. In contrast to this scenario, there is a study by Baradel (2011), where he verified in his empirical unit the compliance with the law and the promotion of regional development through bids. As a final result, it was discovered that despite being structured in a documentary way through decrees and laws, the instruments used to choose suppliers were not sufficient to effect the hiring of MSEs, suggesting that other types of public policies related to the subject are implemented.

Otherwise, we can see in topic 4.1, which deals with contracting public construction by the two towns which are object of the study, in the analyzed period, the non-observance of the one proposed by Complementary Law 123/2006, which provides for the promotion of the participation of MEs and SEs through subcontracting for the execution of construction services, which was not established in the analyzed public notices.

Corroborating with the idea that the agents who act in the purchases of the two towns which were studied must know and understand the Complementary Law 123/2006 in a better way, there is Freitas' study (2012), that found the weakness of disseminating legislation, which is still very recent in Brazil, and Masera (2008), where he found that the lack of preparation of public agents and enterprises contributes to the complementary law that encourages the participation of MSEs regionally established is not being applied in its entirety.

Contrary to what happens in Cerejeiras and Cabixi, where the public notices are still maturing under the terms of Complementary Law 123/2006, it is the IFPE Campus Recife, which, according to Nascimento (2015), promoted sustainable regional development, since $91.83 \%$ of the resources spent were in contracts with MSEs.

\section{Final Considerations}

The objective of this work was to verify whether the bidding notices which were carried out in 2017 and 2018 by the City Halls of Cerejeiras and Cabixi had put regional development foward, under the terms of Complementary Law 123/2006. To this end, all bidding notices were analyzed, which were aimed at acquisition for the health and education departments, published on the transparency portals of these two towns.

The analysis resulted in the fact that both towns have little knowledge about Complementary Law 123/2006, since the notices do not contemplate deeper aspects of the law. In general, the two towns are fully aware of the tiebreaker criteria and deadlines for documents delivery that MSEs are entitled to. In relation to the other aspects, it was observed that the City Hall of Cerejeiras, from April 2018 onwards, began to establish criteria of preference for enterprises headquartered locally or regionally in a correct way before the legislation. While Cabixi established the restriction of competitiveness, trying to establish preferences for MSEs. Following the definitions of Baradel (2011), who said that many advances are needed in discussions about the purchasing power of public agencies?

Despite the delimitation in the analysis of notices from only two departments in two years, it is observed that it was a large amount of analyzed bids, which can satisfactorily represent what is applied in these towns. 
As a limitation of this research, it is understood that the reasons for not using the criteria of Complementary Law $123 / 2006$ in its totality should be verified through a qualitative survey, in order to reveal the real reasons for the problems encountered and, thus, suggest opportunities for improvement, including a recommendation for future research. Another recommendation for a valid study would be to analyze larger towns in the state of Rondônia that need more time for researching, as they have more expressive bids to be analyzed.

The main contribution of this research revolves around demonstrating how much the smaller public agencies do not have adequate qualification to practice legal acts, and with that, they end up suffering inspections and penalties by external control agencies and they need this to stimulate enterprises that are in their region.

Similar to the study by Baradel (2011) that found the promotion of regional development did not occur, despite the publicity forecast, in the units studied at the University of São Paulo, in response to the central research problem, it was concluded that the regional endogenous development of Cerejeiras and Cabixi have not been implemented in their magnitude, and can be expanded in several aspects, such as establishing a public notice: subcontracting MSEs in construction bidding, increasing the exclusivity of bids to MSEs, allocating participation quotas to MSEs in bids whose acquisition is of greater value and that the goods to be acquired are divisible, and finally, to establish more concise and adequate criteria in light of the legislation regarding the preferential contracting of regionally based enterprises, not only aiming at the supply of goods, materials and services that need to be close to the city hall sectors, but also the other ones.

Thus, the hypothesis proposed in this work was confirmed, as the two towns are still unable to establish in their instruments for selecting suppliers, criteria that promote endogenous regional development effectively and according to the legislation in force.

The results of this research can be used by the managers of these towns to promote the verification of flaws in the contracting instruments and the consequent improvement in the notices to promote the development of micro and small enterprises, especially those headquartered regionally.

\section{References}

Amaral Filho, J. (1996). Desenvolvimento regional endógeno em um ambiente federalista. Public Planning and Policies, 14, 35-74. Retrieved from https://www.ipea.gov.br/ppp/index.php/PPP/article/view/129/131

Baradel, E. M. (2011). Licitação como instrumento de política pública de desenvolvimento regional. Master's thesis, Escola de Administração de Empresas de São Paulo, Fundação Getúlio Vargas, São Paulo, Brasil. Retrieved from https://bibliotecadigital.fgv.br/dspace/handle/10438/9241

Barreto, L. K. S., Montenegro, C. B., Souza, K. B. M., Rocha Neto, M. P., \& Souza, P. V. D. (2014). Licitação como uma ferramenta estratégica de crescimento e manutenção para as microempresas e empresas de pequeno porte. Revista Global Manager, 1(14), 1-18. Retrieved from http://ojs.fsg.br/index.php/global/article/view/1101

Bidding Notice. (2017). Air Conditioning Maintenance. Cerejeiras City Hall. Retrieved Abril 12, 2019, from https://ajucel.s3.amazonaws.com/uploads/anexo/pm_cerejeiras/Licitacao/1967/Edital_de_Preg\%C3\%A3o_Pres encial_052_-_17_-_Manut._de_Ar_SEMED.pdf

Bidding Notice. (2018). Remodelling Health Unit Building. Cabixi City Hall. Retrieved December 12, 2019, from https://ajucel.s3.amazonaws.com/uploads/anexo/pm_cabixi/Licitacao/12422/EDITAL_TOMADA_DE_PRE\%C 3\%87OS_04-18.pdf

Bidding Notice. (2018). Tonner refill. Cerejeiras City Hall. Retrieved Abril 12, 2019, from https://ajucel.s3.amazonaws.com/uploads/anexo/pm_cerejeiras/Licitacao/46533/Edital_de_Preg\%C3\%A3o_Pre sencial_012_-_18_Recargas_de_Toners_-_SEMED.pdf

Bidding Notice. (2017). Electronic Auction no. 46/2017 - SEMUSA. [Sheet fabric], Cabixi City Hall. Retrieved December 12, 2019 from https://ajucel.s3.amazonaws.com/uploads/anexo/pm_cabixi/Licitacao/1127/EDITAL_PE_46.pdf

Braga, R. M. L., \& Xavier, F. M. (2011). Impactos da lei geral das micro e pequenas empresas no desenvolvimento das compras públicas do Ceará. Revista Micro e Pequena Empresa, 5(1), 51-67. Retrieved from http://www.spell.org.br/documentos/ver/5884/impactos-da-lei-geral-das-micro-e-pequenas-empr---

Braga, T. M. (2002). Desenvolvimento local endógeno: entre a competitividade e a cidadania. Revista brasileira de estudos urbanos e regionais, 5, 23-37. https://doi.org/10.22296/2317-1529.2001n5p23 
Cabral, S., Reis, P. R. C., \& Sampaio, A. H. (2015). Determinantes da participação e sucesso das micro e pequenas empresas em compras públicas: uma análise empírica. Revista de Administração, 50(4), 477-491. https://doi.org/10.5700/rausp1214

Chapuis, G. A. L. (2019). Compras públicas e desenvolvimento local: um estudo no instituto federal de educação, ciência e tecnologia de Rondônia. Master's thesis, Programa de Pós Graduação em Administração, Fundação Universidade Federal de Rondônia, Porto Velho - RO, Brasil.

Complementary Law. (2006). Institution of National Statute for Small Enterprises and Small-Sized Enterprises. $\begin{array}{llllll}\text { Brasília, } & \text { DF. } & \text { Brasil. } & \text { Retrieved } & \text { September } & 2819\end{array}$ from http://www.planalto.gov.br/ccivil_03/Leis/lcp/lcp123.htm

Creswell, J. W. (2010). Projeto de pesquisa: métodos qualitativo, quantitativo e misto. Porto Alegre: Artmed.

Cunha, M. A. S., \& Bourlegat, C. A. Le. (2016). Inclusão e perspectivas de desenvolvimento da microempresa e empresa de pequeno porte no processo de compras governamentais na esfera federal. Interactions, 17(3), 410-421. Retrieved from https://www.scielo.br/pdf/inter/v17n3/1518-7012-inter-17-03-0410.pdf

Decree. (2017). It regulates the differentiated, facilitated and favoured treatment for small enterprises and small-sized enterprises, family and individual farmer workers, individual microentrepreneurs and consumer cooperative societies on public hiring of purchases, services and construction within Municipal Public Administration. Retrieved December 12, 2019, from https://ajucel.s3.amazonaws.com/uploads/anexo/pm_cabixi/Ato/1439/open-uri20170630-12748-u363g0

Ferreira, D., \& Giusti, A. F. C. O. (2012). A licitação pública como instrumento de concretização do direito fundamental ao desenvolvimento. Revista de Direito Administrativo \& Constitucional0, 12(48), 177-193. https://doi.org/10.21056/aec.v12i48.185

Freitas, T. (2012). Aquisições públicas sustentáveis: o princípio da sustentabilidade encarado para além da questão. Revista Brasileira de Políticas Públicas, 2(1), 83-94. https://doi.org/10.5102/rbpp.v2i1.1678

Law. (1993). It regulates art. 37, subparagraph XXI, of Federal Constitution, and it estabilishes rules for bidding and contracts of Public Administration and other provisions. Retrieved October 1, 2019, from http://www.planalto.gov.br/ccivil_03/Leis/18666cons.htm

Masera, E. F. S. (2008). O Papel das Compras Governamentais no Desenvolvimento das Microempresas e Empresas de Pequeno Porte nas Contratações Públicas. Especialização em Gestão de Programas e Projetos Educacionais do FNDE. Retrieved from https://bdm.unb.br/bitstream/10483/1499/1/2008_ErivanFernandesdeSenaMasera.pdf

Nascimento, S. W. (2015). O Fomento às micro e pequenas empresas por meio de tratamento diferenciado nas licitações realizadas pelos governos. Revista do CEPE, 42, 25-41. https://doi.org/10.17058/cepe.v0i42.5623

Rocha, D. T. M., Ferreira, L. C., Rodrigues, R. A., \& Soares, M. F. (2013). Desenvolvimento de política de compras a microempresas, empresas de pequeno porte e microempreendores individuais no estado de Pernambuco. Anais do VI CONSAD Public Management Congress, Brasília, DF, Brasil. Retrieved from http://consad.org.br/wp-content/uploads/2013/05/183-DESENVOLVIMENTO-DE-POL\%C3\%8DTICA-DE-C OMPRAS-A-MICROEMPRESAS-EMPRESAS-DE-PEQUENO-PORTE-E-MICROEMPREENDEDORES-IN DIVIDUAIS-NO-ESTADO-DE-PERNAMBUCO.pdf

Saunders, M., Lewis, P., \& Thornhill, A. (2016). Research Methods for Business Students (7th ed.). Essex, England: Pearson.

\section{Copyrights}

Copyright for this article is retained by the author(s), with first publication rights granted to the journal.

This is an open-access article distributed under the terms and conditions of the Creative Commons Attribution license (http://creativecommons.org/licenses/by/4.0/). 